

\title{
Expo2020 Dubai on the journey to achieve the United Arab Emirates' Soft Superpower
}

\author{
Adam Krzymowski \\ College of Business Administration - University of Sharjah \\ Sharjah - U.A.E.
}

Received on: 26-06-2019

Accepted on: 23-09-2019

\begin{abstract}
:
This paper presents an analysis of the role and significance of Expo2020 Dubai for UAE soft power in connection with the current and future global strategic challenges. The New World Order that emerged after the fall of the Soviet Union, when President Bush Sr proclaimed a "new world order" at the time of the Gulf War in 1991. Now, we have a stage of global political and economic chaos with no grand winners and a greater number of losers. Fast forward 30 years later, in 2021, we need connecting minds, creating a future that frees the world of wars and political strife, and its promises to eradicate poverty, disease and hunger. The plethora of initiatives may have a positive impact on Asia, but there is also the risk that fierce competition may result in unprofitable projects, while the economic slowdown could cause a decline in funding. Expo2020 Dubai is a great soft power tool, as well as a contribution to the newly emerging international system.
\end{abstract}

Therefore, the researcher put the main question: what is Expo2020 Dubai' role and significance for UAE soft power strategy and dynamics of international relations.

The accepted hypothesis is that Expo2020 Dubai has a great opportunity to be added value for building a new global order.In order to conduct scientific research, the author used many theoretical methods and tools, including the use of neorealist theory, analysis of constellations of interests, or neo-institutional theory. In addition, due to the researcher's participation in many of the processes studied, the work is also based on personal experience. In this sense, the research study has scientific as well as practical importance.

Keywords: Soft Power, Expo 2020 Dubai, International Branding, United Arab Emirates, International Relations. 
Expo2020 Dubai on the journey to achieve the United Arab Emirates' Soft

Superpower (1-21)

\section{Introduction:}

The objective of the research is to study Expo as the largest global mega event which attracts countries and nations around the world, as well as international organizations, non-governmental organizations, universities, public and private sector. It is a great opportunity to establish new relationships and enhance cooperation. Moreover, an Expo is a global platform for new ideas, new technologies, and innovations. Therefore, this global mega event is a huge tool for soft power which means: the ability to influence others through networks along with the ability to persuade according to our goals (Nye, 2004). In 1851, London organized the first World Expo. There, the world was shown a lot of inventions, such as the telephone, the typewriter and the elevator. Additionally, well-recognized buildings constructed for Expo, like the Eiffel Tower or the Statue of Liberty were showcased. Since 1931 Expos have been overseen by the Bureau International des Expositions (BIE), which is an intergovernmental organization.

The problem of the study concerns Expo as one of the world's most important mega events for soft power. Expos give great opportunities for public diplomacy and improving a country's brand (Saberi et al., 2018). Expo 2020 Dubai will be from the 20th of October 2020 till the 10th of April 2021, and it is the first World Expo to take place in the Middle East, Africa, South Asia, and Arab countries. This mega event is the largest expo in history with more than 192 participating countries. Expo 2020 Dubai has a very important voice in the context of a legacy in building a new global order. This exposition fits into the idea of corporate world order, which comes from the interdependence of nations. To ensure that, in line with the UAE interests, the development of this new global architecture, the UAE needs to increase the number of impact instruments as well as their effectiveness in the implementation of the Soft Power Strategy and UAE Centennial 2071.

In the research study, the author formulated the main question as follows: what is the role and significance of Expo2020 Dubai for UAE soft power strategy and dynamics of international relations? As a response to this question, the researcher postulated the hypothesis that Expo2020 Dubai 
has a great opportunity to be added value for building a new global order. In order to conduct scientific research, the author used many theoretical methods and tools, including the use of neorealist theory, analysis of constellation of interests, or neo-institutional theory. In addition, due to the researcher's participation in many of studied processes, the work is also based on personal experience. In this sense, the research study has scientific as well as practical importance.

\section{The problem of the study, methodology and literature review:}

The research problem undertaken is important because it shows and analyzes the most important mega event in the history of the UAE, in relation to its international position and the changing global architecture of international relations. The paper aims to present research on the role and importance of the Expo for the UAE to achieve the position of a soft superpower.

The approach presented in this article is a new one. Although there is already a large corpus of literature related to soft power, linking it with the Expo 2020 Dubai and with the new emerging architecture of international relations expands knowledge about this problem. Regarding the current knowledge and literature of the subject, there is a very interesting analysis by Richard Woodward from Coventry University, who is a specialist in global governance and mega-events. An interesting, valuable study on soft power, hard power, as well as smart power and sources of national strength related to the UAE strategies has been conducted by the UAE National Defense College. Another relevant study that dealt with soft power in GCC is the work of Steffen Hertog, from the London School of Economics and Political Science. Moreover, interesting research on UAE power from a geopolitical perspective is demonstrated by Eleonora Ardemagni, from the Italian Institute for International Political Studies (ISPI) and Justin Gibbins from Zayed University. Another perspective: soft power and UAE as a tourist destination branding shows us the research work done by Donya Saberi, Cody Morris Paris, Belisa Marochi from Middlesex University Dubai. The last study that deserves mentioning is the research on UAE Soft Power in the International Context by Ahmed M.J. Al Suwaidi. 
Expo2020 Dubai on the journey to achieve the United Arab Emirates' Soft Superpower (1-21)

This research was conducted using a descriptive-analytical method. The researcher analyzed source materials, research materials on the subject, as well as observations of personal diplomatic activities in multilateral fora. Also, a wide range of theoretical instruments were used to investigate this issue, in order to analyze the problem in the multilevel approach to international relations. Moreover, this research is based on the neorealist theory of international relations and the concept of international constellation analysis. On the other hand, the theory of neo-institutionalism allowed for the precise mythologizing general and specific functions of international institutions. Even though the constructivist theory is primarily based on national constellations, it ascribes even more significance to international institutions and their super-nationally anchored norms and ideas than the rational institutionalism does. For that reason, it was also taken into consideration. In these analyses, the school of social constructivism theory was also utilized.

\section{UAE Soft Power Strategy:}

In April 2017, Vice President, Prime Minister and Ruler of Dubai, His Highness Sheikh Mohammed bin Rashid Al Maktoum launched the UAE Soft Power Council with Mohammed Abdullah Al Gergawi, Minister of Cabinet Affairs and the Future, who is also the Chairman (WAM, 2017). The Council's most important task was to implement a soft power strategy for the UAE and to coordinate actions taken by the public as well as the private sector. Then, in September 2017 during the UAE governmental annual meetings the UAE Soft Power Strategy was launched (Woodward, 2018). The strategy has four fundamental goals with seven pillars of action. The first objective focuses on coordinating many sectors' tasks, among others: the economy, humanities, tourism, media, and science. The second objective underlines the need to continue promoting the UAE as a gateway to the region. The third objective demonstrates the will to enhance UAE's position as the regional capital for culture, art, and tourism. The fourth objective focuses on building a modern and tolerant country. Those objectives have six main pillars, which form the framework of the strategy (MOCAF, 2017). All the main pillars are connected with UAE's public diplomacy, including: humanitarian, scientific and academic diplomacy, 
national representatives diplomacy, people diplomacy, cultural and media diplomacy, as well as economic diplomacy.

A crucial element of soft power is the country's brand (Günek, 2018). Therefore, the aim of the strategy is to continue enhancing the UAE' global reputation by consolidating and coordinating its actions and investing more in culture, humanitarian aid, as well as economic diplomacy as H.H. Sheikh Mansour bin Zayed Al Nahyan, Deputy Prime Minister of the UAE and Minister of Presidential Affairs, underlined. Additionally, Saeed Mohammad Al Eter, Director-General of the Public Diplomacy Office at the Ministry of Cabinet Affairs and the Future and member of the Soft Power Council, explained that the soft power strategy highlights the vision and comprehensive framework for UAE's actions in expanding its position in the world (Gulf News, 2017). The UAE's Soft Power Strategy underlines a very important role of cultural diplomacy and demonstrating the UAE as a stable, modern and open country with great tolerance.

\section{Tolerance and Peace:}

A fundamental matter for the UAE's soft power strategy is tolerance and peace. In December 2012, HH Sheikh Abdullah bin Zayed Al Nahyan, Minister of Foreign Affairs and International Cooperation, launched "Hedayah" (Arabic for guidance), in Abu Dhabi to counter violent extremism. Hedayah, whose official name is "The International Centre for Excellence", serves as the premier international hub for policymakers, practitioners, and researchers of Counter Violent Extremism (CVE) to enhance understanding. It addresses current threats in CVE by organizing capacity building activities and workshops. Moreover, In July 2015, the United Arab Emirates and the United States of America co-founded "Sawab" Center. (In Arabic, sawab means the right path). It is an online engagement initiative, in support of the global coalition against extremism. Sawab seeks to give a voice to the millions of Muslims and others around the world who stand united against terrorism and the religious misinterpretations that are being propagated. (Government.ae, 2019).

In 2016, Sheikha Lubna Al Qasimi was appointed as the first Minister of State for Tolerance. In June of same year, the UAE Cabinet approved 
Expo2020 Dubai on the journey to achieve the United Arab Emirates' Soft Superpower (1-21)

the National Tolerance Program. Then, in 2017 H.H. Sheikh Nahyan bin Mubarak Al Nahyan approved that position. In June 2017 the International Institute for Tolerance was established in Dubai to promote UAE as a model of tolerance, regionally and globally, as well as to face challenges of extremism. Moreover, to honor people who are engaged in promoting tolerance, Mohammad Bin Rashid Al Maktoum Tolerance Award was established (UAE Cabinet, 2019).

Another very important action to promote tolerance and peace was the establishment of the Global Council for Tolerance and Peace (GCTP). On the 13th of July 2017 an MoU was signed between Ahmed bin Mohammed Al Jarwan (from the UAE), the Chairman of the Constituent Council of the GCTP, and the UN Population Fund (UNFPA) at the headquarters in New York, with the aim of cooperating and building international partnerships about values of tolerance and culture, rejection of extremism, promotion of preventive diplomacy, support of regional and international youth initiatives, launch of a major international award, and contribution to the protection of international peace. Then, on November 2017 in Malta was the official launching of the Global Council for Tolerance and Peace (GCTP). The UAE is one of the founders of the GCTP, along with the US, Argentina, Indonesia, India, Egypt, Albania, Comoros, Malta. One of the parts of the organization is a parliament ( 1 member from 1 country, with sessions every four months). Another part is the General Assembly (members from: governmental institutions, NGO's, universities and think tanks, and high profile persons recognized in activities of tolerance and peace. Sessions should be yearly (GCTP, 2017). The main areas of activities of the GCTP are education and media.

In November 2018, the International Institute for Tolerance organized the first World Tolerance Summit in Dubai (WTS 2018) with more than 1,500 government leaders (Ardemagni, 2019). On 15 December 2018, the President, His Highness Sheikh Khalifa bin Zayed Al Nahyan established the Supreme National Committee for Tolerance in the UAE to celebrate 2019 as the Year of Tolerance. The Committee is chaired by Sheikh Abdullah bin Zayed Al Nahyan, Minister of Foreign Affairs and International Cooperation (WAM, 2018). The most important message was 
setting the UAE as a global capital for tolerance. The Year of Tolerance started with Pope Francis's visit to the UAE. It was the first historical visit paid by the head of the Roman Catholic Church to the Arabian Peninsula (Diwan, 2019).

\section{Humanitarian Aid:}

On 4 October 2015, Mohammed Bin Rashid Al Maktoum Global Initiative was inaugurated, and it was a part of His Highness's vision to contribute to a better world. The humanitarian aid is one of the main tools in producing a good image of the UAE, as well as contributing to the country's soft power (Gibbins, 2017). The Organization for Economic Cooperation and Development (OECD) demonstrated in 2017, for the fifth time, that the UAE is the world's largest Official Development Aid donor, donating AED 19.3 billion to 147 countries, looking at national income (The National, 2018). According to the UAE Policy for Foreign Assistance (2017 - 2021), humanitarian aid is an important part of the UAE's overall foreign assistance (MOFAIC, 2019). Moreover, the UAE expanded on its role as a hub for humanitarian aid and as being a partner in many international projects together with international multilateral organizations.

\section{Soft Power Infrastructure:}

At the very heart of the UAE's soft power strategy are universities. In the UAE there are 32 branch campuses of foreign universities, among others, Sorbonne University and New York. It is a unique achievement at a global level. (Woodward, 2018). The role and importance of Sharjah should be emphasized as a place of science, education and the capital of culture. In the Peninsula, Sharjah is a pioneer in organizing the International Book Fair since 1982 (Ardemagni, 2019). In 2019, Sharjah became the World Book Capital. Moreover, the attention of the world was focused on the Louvre Abu Dhabi, which opened in 2017. Sports fans, around the world, especially from the football clubs, associated Emirates with their favorite clubs. Politicians and experts recognize the UAE as the location that hosts the headquarters of the International Renewable Energy Agency, while the leaders of the country are searching for global new solutions for renewable energy sources (Hertog, 2017). 
Expo2020 Dubai on the journey to achieve the United Arab Emirates' Soft Superpower (1-21)

Worth emphasizing, too, is the role of financial services. According to rankings by total assets, Abu Dhabi Investment Authority ranks as the third, while the Investment Corporation of Dubai ranks in the twelfth position in the world as the largest Sovereign Wealth Funds (SWFI, 2019). Tourism, both business and leisure, logistics and transport, strengthen the significant position of the UAE. Since the UAE's establishment, investments in transport infrastructure were of the highest importance, by building around $5,000 \mathrm{~km}$ of roads and highways that are permanently being developed. In the economic development of the Emirates, seaports and airports play an important role. Port Jebel Ali is a leading global container terminal that is a key element of the infrastructure. An increasingly important role is played by the new port, Khalifa Port, located between Abu Dhabi and Dubai. In total, UAE operates 21 ports, including 11 seagoing ports. Currently, the UAE has 12 airports ready to receive the largest aircraft, including Dubai International Airport, which is a port serving one of the largest numbers of passengers in the world. Moreover, Abu Dhabi International, which is currently undergoing a significant expansion should reach 30 million serviced passengers per year. Also, there is a huge investment in the expansion of Al Maktoum International Airport, located near the site of the future world exhibition Expo 2020 Dubai. Ultimately, the port is to be the largest in the world, servicing 220 million passengers annually and forming part of the new Dubai business center that will be built on the Expo2020 site in Jebel Ali. UAE airlines, especially Emirates Airlines, which is one of the largest airlines in the world, plays a very important role in ensuring development and tourism.

\section{Space Program:}

In the process of building a new global order, there is an increase in the importance of space power. Space power should be a very important element of strategy for strong and fast development, and it has a strong impact on foreign and security policy and future prosperity. World Expo 2020 Dubai is a fantastic opportunity to build a global platform for creating new architecture in many areas.

Currently, the UAE is building a strong space industry as an important element of national prestige. UAE Space Policy and the space industry 
should support the efforts of scientific research and innovation. Space power should be a crucial element of national power and protect the UAE's interests. Dubai Expo 2020, will be the first World Expo to take place in the Middle East, Africa, South Asia, and Arab countries, and its space mission will be the first-ever Arab mission to another planet in history. The UAE should have a strong foundation for having its own research and innovation centers.

The Mars program and sending a UAE probe to Mars in 2021, on the UAE's 50th anniversary should open new horizons and perspectives. The program is supported by two Emirati institutions. The UAE Space Agency finances and supervises the program, while the Mohammed bin Rashid Space Centre (MBRSC) develops the program in cooperation with foreign organizations. The UAE will be one of only nine countries with ambitions to explore Mars, and the unmanned probe will travel more than 60 million kilometers in nine months and will be launched to coincide with the UAE's 50th anniversary. The objectives of the mission are: to build Emirati human capital skilled in space technology; to develop knowledge, scientific research, and space application that will benefit humanity, and to build a sustainable knowledge-based economy, promote diversification and encourage innovation (UAE Space Agency, 2019).

\section{Connecting Minds, Creating the Future:}

The very important project that the UAE counts on, that will contribute to the image and economic success, is the World Exhibition EXPO 2020 in Dubai which is the first Expo organized in the Middle East, Africa, and South Asia. UAE selected the theme "Connecting Minds, Creating the Future" with sub-themes of Sustainability, Mobility, and Opportunity. Expo2020 Dubai with its many projects will be a great opportunity for the UAE to become a soft superpower. Expo 2020 has close cooperation, not only with official, governmental participants, but also with non-official Participants Cooperation with Universities, Research, and Academia institutions, NGO's, Global Initiative, and Foundations. This is added to the Expo Live Innovation Impact Grant Programme, which is very useful for soft power strategy. The program's goal is to support innovative solutions related to the Expo's three sub themes: Opportunity, Mobility, and Sustainability. 
Expo2020 Dubai on the journey to achieve the United Arab Emirates' Soft Superpower (1-21)

The Innovation Impact Grant Program allocates USD 100,000 to support the growth of social enterprises, startups, and grassroots projects from around the world whose solutions generate real social value. The program calls for individual entrepreneurs, SMEs, not-for-profit organizations, or government-related entities to submit their solutions, which should be at a demonstration and implementation stage (Expo, 2019).

\section{International Projects Competition:}

Dubai Expo 2020 should be the real strategic point of the foreign, security and economic policy of the UAE for creating future interests according to the UAE. Currently, it is an emerging new architecture of the multipolar world. The biggest risk of expanding multipolar architecture is the lack of stability in the global hierarchy. Moreover, for some countries, Dubai is a competitor, as a hub. This includes building alternative routes for the Silk Road, which the Chinese President Xi Jinping proclaimed as an Economic Belt ("One Belt, One Road") in 2013, providing an overarching framework for understanding China's strategic priorities over the coming decade. The Silk Roads will connect Asia and Europe through the Middle East as well as Central Asia using and building new seaports, railroads, airports, and pipelines (FMPRC, 2013). The New Silk Road strategy is a very important global tool for the foreign policy of China. As a consequence of this, it will be a base for the development of Chinese political influence and will enable a non-formalized formula of multilateral co-operation to be built. The maritime route may legitimize the intensified presence and activity of the Chinese navy in the World Ocean under the pretext of protecting Chinese trade. The New Silk Road concept offers not only a point of reference, which is an alternative to the US dominance, especially in East Asia, but also about other powers in Eurasia such as Russia or India. In the long term, the concept will become an element of the construction of the Chinese international order, which is an alternative to the one dominated by the United States. In terms of the Middle East's position in the Silk Road, China focuses on doing and expanding the business as usual. The New Silk Road concept is also a way to enhance cooperation between China and Turkey. From a Chinese perspective, the Gulf does not have much to offer beyond oil and gas resources. The original route bypassed most of the Middle East, 
but the modern version encompasses both a land route through Central Asia and a new maritime Silk Road, which could more easily involve Gulf ports. Showing different routes concept has also aimed to boost the role of China in consultation with their partners, including the UAE.

Europe is China's most important economic partner. Even if the project is implemented in part, China will have better access to the European market and will find it easier to enhance cooperation with the EU. Central and Eastern Europe (CEE) may play an essential role (with its maritime and inland ports) as a transit area and a place of entry to the Western European market. Furthermore, CEE countries could be used as a forum, where Chinese products can be improved and marketed before they are fully introduced to the European market. The planned high-speed railway connecting Belgrade and Budapest is a flagship project as a part of connecting the maritime and land routes of the New Silk Road. The 2 billion euros it costs will be paid for by China's Exim Bank, and the construction work will be entrusted to the state-owned China Railway and Construction Corporation (Juvin, 2019).

The new world order requires a re-assessment of strategy and policies, especially in the context of declining oil prices and possibly reducing its significance. In the emerging new world order, the concept of the New Silk Road can play an important role. When Chinese exporters look around the world, the Gulf appears as a fairly small market with limited potential. The New Silk Road is a game-changing development for the logistics industry and global trade. It is also important to take account of the Transatlantic Trade and Investment Partnership (TTIP) with the world's largest free trade zone. The agreement covers: facilitating services and carrying out investments, energy trading (mainly of shale gas), and agriculture (European Commission, 2019). TTIP strength both actors that political and economic growth of Asia does not mean a loosening of transatlantic ties.

In mid-March 2016, the Chinese parliament adopted the five-year guideline, covering the period 2016-2020. In 2021 the Communist Party of China will celebrate its anniversary of 100 years. The main goal of the plan is to achieve a "moderately prosperous society", which means building up the middle class by 2020. This is the first official economic roadmap to be 
Expo2020 Dubai on the journey to achieve the United Arab Emirates' Soft Superpower (1-21)

announced since China's economic growth hit its slowest pace in 25 years, and it comes after three spectacular stock market plunges in mid-2015 and early 2016. The plan indirectly confirms the intent to maneuver between state intervention and market forces. The guideline assumes huge infrastructure projects, including thousands of kilometers of high-speed railways and highways and more than 50 new airports. Despite the slowdown, and even anticipating lower than planned GDP growth, it seems that China will remain a global economic engine for the next five years. Europe seems to be a likely partner to help China facilitate the implementation of its fiveyear plan, through the "Silk Road" and "Juncker Plan" as instruments for greater involvement (EIF, 2018).

Another initiative that aims to address infrastructure congestion has been announced by the Republic of Korea. This policy, known as the "Eurasia Initiative" and advertised as the Grand National strategy, was unveiled by Korea's president in October 2013, just a few days after Xi Jinping's declaration about the Silk Road. Moreover, the Korean proposal uses similar buzzwords, such as the name of the main railway connection (the Silk Road Express, SRX) and the general slogan "One Dream, One Eurasia." The "Eurasia Initiative" is based on three pillars. The first being "Connectivity," assume connecting Asia via infrastructures such as oil and gas pipelines, a logistics and energy network, intermodal facilities and new land and maritime transport lanes. The main focus is on infrastructure and transport. The second pillar is "Creativity," which indicates that Asia, as an engine of the world's growth, needs reforms because its comparative economic advantages (such as the huge population and cheap workforce) are coming to an end. Under these circumstances, Asia is required to formulate a new type of growth that should be based on science, technology, ICT and innovation. The third pillar, "Peace and Trust Building," pays special attention to security threats in Asia (for example, problems with North Korea), which are serious impediments to trade, investment, and general development (Taehwan, 2015).

On 21 May 2015, Prime Minister of Japan Shinzō Abe announced an investment worth $\$ 110$ billion for infrastructure in Asia within the framework of the "Partnership for Quality Infrastructure: Investment for 
Asia's Future" five-year initiative. This announcement was made after the fourth round of talks about the Asia Infrastructure Investment Bank (AIIB). In that sense, Japan's new policy is perceived as a response to the AIIB, and the amount of money proposed by Japan is slightly higher than the founding capital of the AIIB ( $\$ 100$ billion). The core of Japanese initiative is infrastructure development in Southeast, Southwest and Central Asia. Japan is trying to differentiate from the OBOR and the AIIB, with a focus on "quality infrastructure investments." This means environmentally friendly, disaster resilient projects that are cost-effective in the long run, create jobs for local people, increase local skills and improve people's lives. Additionally, all investments should be based on each country's development plan (MOFA, 2015). The first signal of this approach was in 2015. It is important for underdeveloped northeastern states, in particular, and to India's global ambitions, to improve connectivity with Myanmar and further east with ASEAN states. India supports building a bimodal transport corridor in Myanmar and a trilateral highway leading further to Thailand and Vietnam. On the western border, India has joined the long-planned TAPI pipeline (Turkmenistan-Afghanistan-PakistanIndia) despite concerns over cooperation with Islamabad, and the project eventually started last year. The end of sanctions against Iran may soon revive another transnational pipeline project, the IPI, and boost another ambitious infrastructure dream, the North-South Transport Corridor. Indian companies have for years been active in refurbishing the Iranian port of Chabahar on the Gulf and connecting it to the Iranian network, and this project could be a useful complement to the east-west transport corridors planned along China's OBOR and connecting the EU with South Asia and ASEAN states. India's problem, however, is the lack of capital and technologies compared to China.

ASEAN's two rising neighbors, India and China, and the fact that they are geographically disparate and not cohesive, in terms of economic development or the size of individual countries or political regimes, leave them with no choice but to address those disadvantages. Under these circumstances, the ASEAN group has its infrastructural initiative which is being implemented, not only by its members, but also by other states, with Japan playing a leading role. It is difficult to describe all infrastructural 
Expo2020 Dubai on the journey to achieve the United Arab Emirates' Soft Superpower (1-21)

projects under the ASEAN "Master Plan" (ASEAN, 2018), but there are at least two flagship investments. The plan assumes the construction of a 38,400 km long ASEAN Highway Network (AHN), encompassing Indonesia, Laos, Malaysia, Myanmar, the Philippines, and Vietnam. The second huge investment is the Singapore-Kunming Rail Link (SKRL), covering Singapore, Malaysia, Thailand, Cambodia, Vietnam and China (Kunming city). Apart from those two main projects, the "Master Plan" assumes the development of the inland waterways, 47 ports, air transport, ICT and energy infrastructure, and more.

\section{Conclusion:}

Dubai Expo2020, as a strategic project and a global platform, needs a strategic approach and deserves strategic analyses and research. We have to know what we are connecting to create the future. The current world is very interactive and interdependent. Connecting minds for creating the future should be natural. However, unfortunately, the major powers have yet to undertake globally cooperative responses to the new and increasingly grave challenges to human well-being - environmental, climatic, socioeconomic, or demographic. Additionally, a world where the problems of human survival have begun to overshadows more traditional international conflicts. The rise to global pre-eminence of new powers highlighted the dispersal of geopolitical power. In this situation, the Asian powers are rivals. The more immediate risk of the ongoing dispersal of power is a potentially unstable global hierarchy. The system would produce a fast-moving chain reaction leading to global political and economic chaos.

Expo2020 Dubai, tolerance programs, academic and cultural projects, as well as humanitarian aid are all instruments for the UAE to become a soft superpower (Aldroubi, 2018). Expo2020 Dubai will strengthen and increase the position of Dubai as a center of trade, business, and finance of the world, and the implementation of the soft power strategy. The New World Order has emerged after the fall of the Soviet Union, when President Bush Sr proclaimed a "new world order" at the time of the Gulf War in 1991. Now, we have a stage of global political and economic chaos with no grand winners and many more losers. 30 years after that, in 2021, we need connecting minds, creating the future to free the world of wars and 
political strife, and its promises to eradicate poverty, disease, and hunger. The plethora of initiatives may have a positive impact on Asia. But there is also the risk that fierce competition may result in unprofitable projects, while economic slowdown could cause a decline in funding. According to Al Suwaidi (2017), if the United Arab Emirates, wants to be more integrated with world economics as well as increase the role and significance of its position, the UAE must follow a soft power strategy.

The UAE's building of a mechanism for cooperation and joint investment would lead to wiser investments in financing economic development in Asia, the Middle East, Africa, and other emerging markets, where the real returns are more promising and a very important part of the project as Central and Eastern Europe. Al Suwaidi (2017) underlined cultural diplomacy as a main element of the strategy by strengthening the soft power of the state, and it should also keep a balance between the openness and guarding national interests. The potential of the digital economy is not fully exploited in the UAE. It can dramatically contribute to innovation, growth, competitiveness, and jobs. How well and how quickly Emiratis businesses adopt digital technologies will be a key for their growth. As Ballard (February 2017) underlines that wide activity of the UAE in international organizations, like International Renewable Energy Agency, provide the UAE with strong diplomatic credibility. The UAE can become a major exporter of solar power energy and technologies. Similarly, nanomaterials are largely hydrocarbon-based, offering great potential for the UAE to use their resources to invest in nanotechnology and become a producer and exporter of nanomaterials and new technology, including space technologies.

Expo lasts for only six months, and growth levels in many of the economic activities in the countries that hosted previous Expos have witnessed a sharp decline after the expiry of the exhibitions. Therefore, it is important to study the stories of successes/failures of those Expos and draw implications for Expo 2020. Moreover, the current world requires a fast response to future challenges and a lot of change in the next few years in global architecture, economy, innovations, politics, alliances systems and human aspirations. All of them will impact the Expo 2020 Dubai and its 
Expo2020 Dubai on the journey to achieve the United Arab Emirates' Soft Superpower (1-21)

readiness to influence global processes. There is a big competition between strategic infrastructure projects in many countries. Massive investments in real estate and different projects and activities were carried out on the expectation that the UAE will undergo big economic growth. How to maintain growth levels and the development tempo expected during Expo 2020? And more importantly, how not just to maintain the Dubai brand name and international image but to expand this brand, leading to the UAE as the best country in the world in 2071 .

Ballard (January 2017) notes that soft power as influence is crucial to national strength. Thanks to Expo2020 Dubai, the UAE can shape a broader geopolitical foundation for constructive cooperation in the global arena. The crisis of global power and foreseen coming economic crisis will be the cumulative consequence of the dynamic impact on the Expo2020 Dubai. Therefore, it is crucial to undertake measures to maintain growth levels and the development tempo expected during Expo 2020, and to take precautions for the expected decline in growth levels after the expiry of the Expo, especially in real estate, tourism, transport, and trade sectors or to minimize its impact.

The world is undergoing major changes and transformations in various political, economic, social and scientific fields, creating real challenges given their profound direct effects on and implications for both human life and the security and stability of states worldwide. Ballard (December 2016) argues that national power, including soft power, should be coordinated. The annual UAE Government meetings in September 2017 have approved a working mechanism to realize the UAE Centennial 2071 goals. His Highness Shaikh Mohammad Bin Rashid Al Maktoum, Vice-President and Prime Minister of the UAE and Ruler of Dubai, stressed that the UAE laid down strong foundations for government work, which support the UAE's approach and journey for realizing UAE Centennial 2071 and leading the UAE to be the top country in the world in different fields. Therefore, the UAE, by building strong soft power in long term strategy - UAE Centennial 2071 , wants to achieve the goal to be the best country in the world by 2071 . 


\section{Recommendations:}

- Dubai and the UAE should be the strong world center of innovation, tolerance and the exchange of ideas, culture, and serve as a model in the world of the peaceful cooperation of all the nations of the world for the better today because today is shaping tomorrow. Expo2020 Dubai legacy should establish the world's largest platform of global cooperation.

- Expo 2020 Dubai should ensure that the UAE will be the epicenter of interests for a growing number of shippers in Asia and Europe and the UAE will be a strategic point in the New Silk Road.

- There is a need for strengthening and ensuring the UAE's position as a logistics hub to the other GCC countries, Iran, India, and Africa. UAE seaports and airports are entering a new era of becoming a global logistics hub. However, it can't become a Multimodal Logistics Hub without having a fully integrated Land Transport infrastructure, including a railway system connecting its facilities and connecting the GCC countries.

- UAE can't be a Global Multimodal Logistics Hub, without connecting to the China-Europe-New Silk Road, which requires only $600 \mathrm{~km}$ railway system via the Strait of Hormuz to reach Zahedan and become part of the Chinese proposed Global Railway Network. Expo 2020 Dubai should ensure that DP World and Abu Dhabi Ports Company will provide a key role in the network of the project.

- Expo2020 Dubai should be a great occasion to get access to new technology to develop an industrial partnership to jointly undertake R\&D in Renewable Energy (RE), water resource management and build solar power technology and energy capacity. 
Expo2020 Dubai on the journey to achieve the United Arab Emirates' Soft

Superpower (1-21)

\section{References:}

Aldroubi, M. (2018). UAE to take the international lead on soft power, The National, December 27, 2018 (https://www.thenational.ae/world/gcc/uae-to-take-internationallead-on-soft-power-1.806868)

Ardemagni, E. (2019). The Geopolitics of Tolerance: Inside the UAE's Cultural Rush, 03 febbraio 2019, ISPI (Istituto per gli Studi di Politica Internazionale)

AREA. (2019). (https://area2071.ae/)

ASEAN. (2018). The Master Plan on ASEAN Connectivity 2025 Deliverables for 2018 and ASEAN Connectivity Microsite Launched, November 2018 (https://asean. org/master-plan-asean-connectivity-2025-deliverables-2018-asean-connectivitymicrosite-launched/)

Al Suwaidi, A. (2017). The UAE Soft Power in the International Relations Context, International Journal of Social Science and Humanities Research, Vol. 5, Issue 4, Month: October - December 2017

Ballard, J. (2017). Strategic Approaches The Potent smart-Power of the UAE, National Defense College, 01 February 2017 (http://www.ndc.ac.ae/en/strategic-approachesthe-potentsmart-power-of-the-uae)

Ballard, J. (2016). Strategic Issues: Coordinating National Power, National Defense College, 04 December 2016 (http://www.ndc.ac.ae/en/strategic-issues-coordinatingnational-power)

Ballard, J. (2017). Strategic Issues: Sources of National Strength, 04 January 2017, National Defense College, (http://www.ndc.ac.ae/en/strategic-issues-sources-ofnational-strength)

Diwan, K. (2019). The Pope's Visit and Emirati Soft Power, The Arab Gulf States Institute in Washington, Feb 5, 2019 (https://agsiw.org/the-popes-visit-and-emirati-softpower/)

EIF. (2018). First EU-China investment platform backed by the Juncker Plan, 06 August 2018 (https://www.eif.org/what_we_do/equity/news/2018/silk_road_fund_initiative. $\mathrm{htm})$

European Commission. (2019). The Transatlantic Trade and Investment Partnership (TTIP), 15 Apr 2019 (http://ec.europa.eu/trade/policy/in-focus/ttip/)

Expo. (2019). (https://www.expo2020dubai.com/en)

FMPRC. (2013). President Xi Jinping Delivers Important Speech and Proposes to Build a Silk Road Economic Belt with Central Asian Countries, 2013/09/07 (https://www. fmprc.gov.cn/mfa_eng/topics_665678/xjpfwzysiesgjtfhshzzfh_665686/t1076334. shtml)

18 University of Sharjah Journal for Humanities \& Social Sciences, Volume 17, No. 2 (A) December 2020 
GCTP. (2017). Explanatory Paper of the Global Council for Tolerance and Peace, (http:// gctpnews.org/wp-content/uploads/2018/03/Explanatory-Paper-of-the-GlobalCouncil-for-Tolerance-and-Peace.pdf)

Gibbins, J. (2017). Power play: The United Arab Emirates' new approach to geopolitics, Journal of Middle Eastern Politics and Policy. Cambridge, MA: Harvard Kennedy School of Government (http://hksjmepp.com/united-arab-emirates-geopolitics/)

Government.ae. (2019). Maintaining safety and security 12 Mar 2019 (https://www. government.ae/en/information-and-services/justice-safety-and-the-law/maintainingsafety-and-security)

Government.ae. (2017). (https://government.ae/en/about-the-uae/strategies-initiativesand-awards/federal-governments-strategies-and-plans/uae-centennial-2071)

Government.ae. (2017). (https://government.ae/en/about-the-uae/strategies-initiativesand-awards/federal-governments-strategies-and-plans/the-uae-soft-power-strategy)

Gulf News. (2017). UAE's Soft Power Strategy discussed, Gulf News, September 26, 2017 (https://gulfnews.com/uae/government/uaes-soft-power-strategydiscussed-1.2096694)

Günek, A. (2018). A New Type of Soft Power: Country Branding, International Journal of Cultural and Social Studies (IntJCSS), June 2018: Volume 4 (Issue 1) (https:// dergipark.org.tr/download/article-file/525907)

Hertog, S. (2017). A quest for significance: Gulf oil monarchies' international 'soft power' strategies and their local urban dimensions. LSE Kuwait Programme Paper Series (42). The London School of Economics and Political Science, London, UK.

Juvin, H. (2019). The New Silk Road and the Return of Geopolitics, American Affairs Volume III, Number 1 (Spring 2019) (https://americanaffairsjournal.org/2019/02/thenew-silk-road-and-the-return-of-geopolitics/)

MOCAF. (2017). Mohammad Bin Rashid launches UAE Soft Power Council, 29 April 2017 (https://www.mocaf.gov.ae/en/media/news/mohammad-bin-rashid-launchesuae-soft-power-council)

MOFA. (2015). Announcement of "Partnership for Quality Infrastructure: Investment for Asia's Future" May 21, 2015 (https://www.mofa.go.jp/policy/oda/page18_000076. html)

MOFA. (2017). (https://www.mofa.gov.ae/EN/MediaCenter/News/Pages/28-09-2017UAE.aspx\#sthash.prAp2DR1.dpuf)

MOFAIC. (2019). UAE Foreign AID (https://www.mofa.gov.ae/EN/TheMinistry/ UAEForeignPolicy/Pages/UAEFAR.aspx)

Nye, J. (2004). Soft Power: The Means to Success in World Politics, Foreign Affairs, May/ June 2004 Issue 
Expo2020 Dubai on the journey to achieve the United Arab Emirates' Soft

Superpower (1-21)

Saberi, D. (2018). Paris Cody Morris, Marochi Belisa, Soft power and place branding in the United Arab Emirates: examples of the tourism and film industries, International Journal of Diplomacy and Economy, Volume 4, Issue 1, 2018

SWFI. (2019). Top 81 Largest Sovereign Wealth Fund Rankings by Total Assets (https:// www.swfinstitute.org/fund-rankings/sovereign-wealth-fund)

Taehwan, K. (2015). Beyond Geopolitics: South Korea's Eurasia Initiative as a New Nordpolitik, February 16, 2015, Open Forum, Korea National Diplomatic Academy (http://www.theasanforum.org/beyond-geopolitics-south-koreas-eurasia-initiativeas-a-new-nordpolitik/)

The National. (2018). UAE is the world's top donor of development aid in 2017, report shows, April 9, 2018 (https://www.thenational.ae/uae/government/uae-is-world-stop-donor-of-development-aid-in-2017-report-shows-1.720143)

UAE Cabinet. (2019). (https://uaecabinet.ae/en/details/news/mohammed-bin-rashidlaunches-global-initiative-for-tolerance-openness)

UAE Space Agency. (2019). Hope Probe (https://www.space.gov.ae/Page/20121/20167/ Hope-Probe)

UN. (2007). Press Conference by United Nations Messengers of Peace, 21 September 2007 (https://www.un.org/press/en/2007/070921_Messengers.doc.htm)

WAM. (2017). Mohammed bin Rashid launches UAE Soft Power Council, 29-04-2017 (http://wam.ae/en/details/1395302611062)

WAM. (2018). VP directs formation of 'Supreme National Committee for Tolerance', 1712-2018 (http://wam.ae/en/details/1395302727595)

Woodward, R. (2018). The UAE - Soft Superpower In The Making? TRENDS Research \& Advisory, May 30, 2018 (http://trendsinstitution.org/the-uae-soft-superpower-inthe-making/) 


\section{إكسبو 2020 دبي في الرحلة لتحقيق القوة العظمى الناعمة لاولة

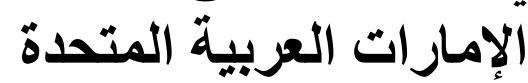 \\ آدم كرزيموفسكي}

كلية إدارة الأعمال - جامعة الثارقة

الثنارقة ـ الإمار ات العربية المتحدة

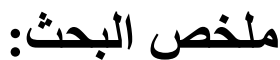

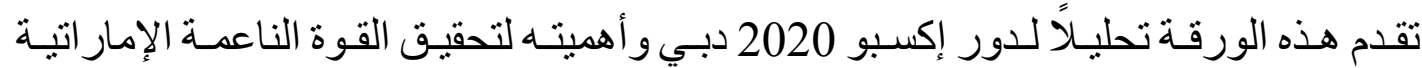

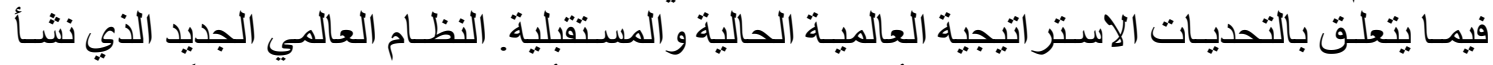

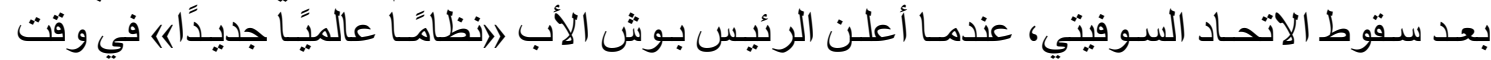

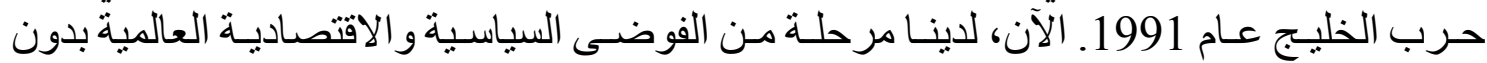

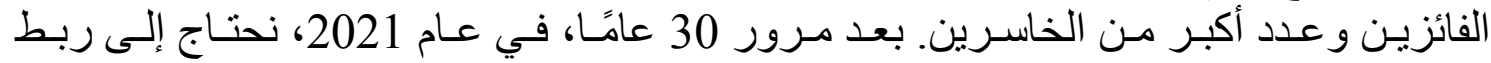

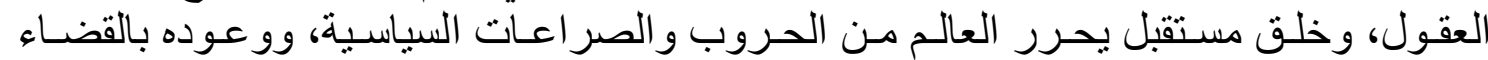

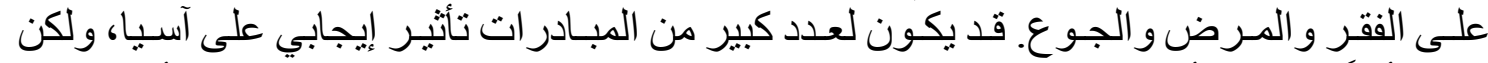

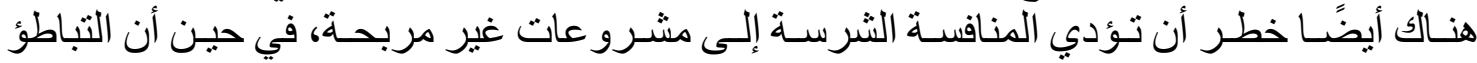

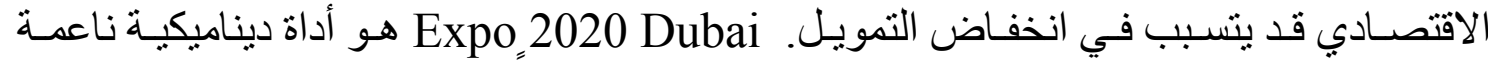

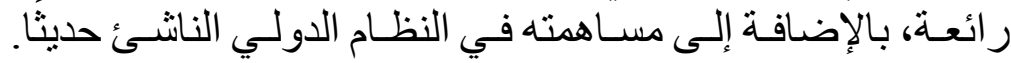

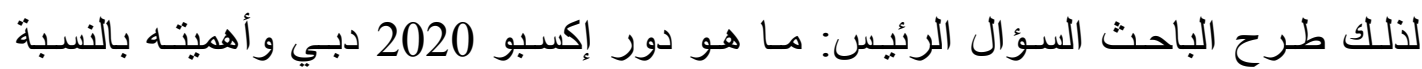

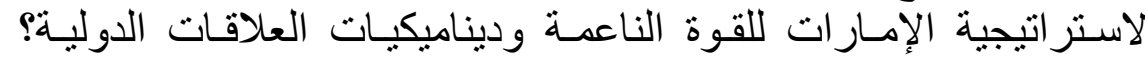

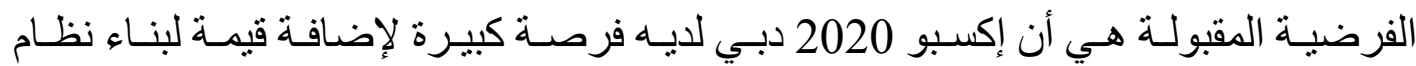



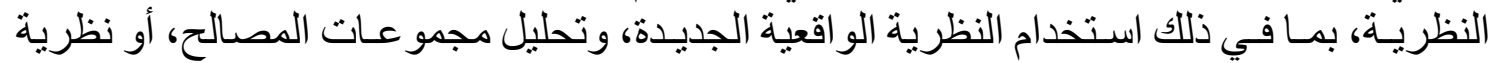

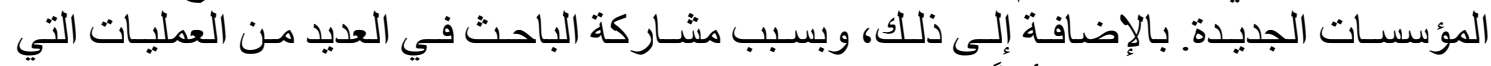

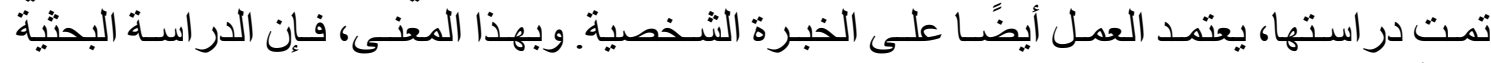
لها أهميـة علميـة وعملية.

الكلمـات الدالـة: Soft Power، إكسبو 2020 دبـي، العلامـات التجاريـة الدوليـة، الإمـار ات

العربيـة المتحدة، العلاقـات الدولية. 